Article

\title{
Communication and Information Flow in Polish Construction Projects
}

\author{
Ewelina Kania *, Elżbieta Radziszewska-Zielina@ and Grzegorz Śladowski® \\ Faculty of Civil Engineering, Cracow University of Technology, 31-155 Cracow, Poland; \\ eradzisz@L7.pk.edu.pl (E.R.-Z.); gsladowski@L7.pk.edu.pl (G.Ś.) \\ * Correspondence: ewelina.kania13@gmail.com; Tel.: +48-601-475-586
}

Received: 26 September 2020; Accepted: 2 November 2020; Published: 4 November 2020

\begin{abstract}
The objective of this paper is to analyse communication and information flow within construction projects on the basis of a survey study and a review of the literature. The subject of communication and its impact on carrying out a construction project is widely discussed in global academic literature. Many scholars point to problems with communication and information flow while also reporting that it directly affects construction project time and cost. In the literature, communication is also presented as an essential factor that improves safety and partnering in construction projects. There is also a group of studies that points to the lack of effective communication as the cause of delays and modifications. The authors, in reference to global studies, present the results of a survey study performed in Poland on a group of 160 construction industry practitioners. Information about five research areas was collected. These areas included: general information about communication and information flow between construction project participants, problems in carrying out construction projects in relation to the lack of effective communication, the impact of communication on the success of carrying out a construction project, communication costs, and the need to develop a tool (a digital system) that would support construction project managers in the optimal control over communication between project participants. On the basis of the obtained research results and the literature study, it was found that effective communication and information flow within a construction project can improve the construction process and that there exists a need to develop a comprehensive approach that would aid construction project managers in ensuring a more effective information flow.
\end{abstract}

Keywords: survey studies; communication; construction project

\section{Introduction}

The development of the construction industry over the years has made construction processes increasingly tied with dynamic and complex activity; awareness of the need for better project management in the construction sector increases [1]. This is partially the effect of increasingly higher client demands concerning design and construction technology, performance, savings and time. Often, design and construction processes are performed in parallel so as to speed up the project $[2,3]$. The pressure exerted by developers on designers increases, as they demand that finished and complete elements of the design will be delivered on time. General contractors become increasingly dependent on subcontractors. As Baldwin et al. [1] observed, demanding construction projects require an increasing number of specialised subcontractors. These changes cause design and construction processes and the coordination of the involvement of many teams to become a serious challenge. Sonnenwald [4] suggests that communication is an important element based on cooperation during the process of design and construction. Communication systems are similar to central nervous systems which allow hundreds of people to perform many tasks and to coordinate their skills and efforts towards achieving a common goal [5]. This is particularly essential in the construction industry [6]. Studies by 
Knoop et al. [7] and Thomas et al. [8] confirmed the significance of communication in the design process in the construction sector.

The objective of the paper was to analyse communication and information flow in construction projects. To achieve this goal, the authors of this paper analysed the literature and carried out a survey study on a group of Polish construction-sector practitioners, filling a gap in global academic literature. The primary focus was placed on the role that communication plays in Polish construction projects, on the impact of communication and information flow on the success of construction projects, the problems that emerge as a result of poor information flow, communication costs, and demonstrating whether there was a need to support construction project managers in controlling information flow using hypothetical computer software that could be developed in the future.

\section{Methodology}

\subsection{Literature Review Methodology}

Source material collection was based on entering combinations of keywords into the SCOPUS and Web of Science search engines. The keywords included the phrases "communication in construction," "information flow in construction projects," "communication management in construction projects." The authors searched for these phrases in titles, abstracts and keyword lists (TITLE-ABS-KEY) of the materials indexed in the databases. The search was confined to academic papers written in English within the engineering discipline over the past thirty years. The search focused on publications that had been cited multiple times.

Afterwards, the authors reviewed the publications, with a focus on studies that impacted the confirmation of research objectives.

\subsection{Research Design and Survey Questionnaire}

The study presented herein discusses the problem of the significance of communication between construction project participants, the many problems related with communication or information flow and its impact on project success. The authors used a survey study for this purpose. Survey studies are a research method that, at the initial stage of research, allows for obtaining useful information that can be used to justify broader academic studies of a given subject and provide tools to solve existing problems [9]. Questionnaire-based survey studies were used to explore many research problems associated with communication in the construction sector, i.e., [10-15].

The authors of the paper prepared a survey questionnaire. The questionnaire was addressed to a purposively selected, non-statistical group-actively practicing construction project participants. The questionnaire comprised an informative section that explained to the respondents the purpose of the study, how to answer each question, and that their identities would remain undisclosed. This was followed by a demographic section and substantive questions about the details of the subject under study.

The demographic questions focused on determining the workplace position of the respondent, the length of their employment in the sector, the cost of the construction projects the respondents participated in and examples of projects that a given expert had participated in. These questions were intended to determine the specialisation of the experts within the construction sector and assess their diversity. They also allowed the authors to obtain information about a given research area while drawing on experience from carrying out a multimillion polish zloty project, and to group answer distribution depending on the length of employment in the construction sector.

The main section included 12 questions. These were both closed-ended questions, open-ended questions, and questions with a mixed structure, that required the answer to be further descriptively explained. As the authors were interested in the five research areas concerning communication, the questions were prepared to allow obtaining the greatest amount of knowledge within the given scope. First, the respondents were asked to write an open statement about general information concerning 
communication and information flow between construction project participants. Subsequently, as part of the questions about the research scope concerning opinions about problems in carrying out construction projects in relation to the lack of effective communication, the authors prepared three questions that aided in determining whether there existed a correlation between communication and the emergence of problems during the carrying out of a construction project. The third set of questions concerned opinions about the impact of communication on the successful carrying out of construction projects, with respondents asked to answer whether there was a correlation between project success and communication and to sequence success factors depending on how significantly they impacted final project success. In the question set that followed, the respondents were asked to answer open questions about the cost of communication. The final section concerned collecting information about supporting communication management in construction projects. The respondents were also asked, via closed-ended questions requiring explanation, how their projects were managed in the context of information flow, and whether they were managed digitally using dedicated software. Opinions were also collected about the need to develop a tool (computer software) that would support construction project managers in the optimal control of communication between the project's participants.

The study was conducted between November 2019 and March 2020 in the form of a direct survey and an online survey. The study was based on a purposive sample, focusing on a group of experts-purposively selected participants who were construction-sector practitioners in their chosen specialisation. Data collection was performed via direct contact between the authors and respondents on construction sites, which enabled expanding the survey study to include freeform interviews with experts and observe the work being performed. The study was also performed online. The survey, in electronic form, was posted to a closed online group whose members were practitioners from the construction sector, in addition to being sent via e-mail to verified respondents who had been identified by previous participants (the snowball method). The data were collected using a Google survey sheet and were later subjected to statistical processing. Altogether, 160 correctly filled out questionnaires were obtained. The results of the tests were evaluated for reliability. The concordance of respondents' preferences was verified using the Kendall concordance factor [16].

\section{Results and Discussion}

\subsection{Analysis of the Literature}

Defining communication is difficult, as it is a multidimensional and non-definable phenomenon. The diversity of meanings, contexts and forms will therefore mean different things to different individuals in different situations. A significant number of authors who study the subject of communication in the construction sector present their own definition of communication. The word "communication" is derived from the Latin words "communicare" and "communicatio" (to transfer information, to communicate), which typically denote bilateral information flow [17]. Den Otter et al. [18] argued that communication is the process of exchanging information between a sender and a receiver with the objective being for both parties to obtain and expand the information at their disposal. Some scholars define communication as a process because of its dynamic character, as it includes the sharing of opinions, ideas and goals. Ayodele [19] pointed out that communication means more than obtaining information, as he noted that information must be reliable, given to appropriate people and should lead to proper reactions. Norouzia et al. [20] confirmed that communication is a complex process and that in the case of construction projects it is a process that ultimately leads to obtaining information essential to the project, thereby ensuring its success. The case of the construction industry is most probably a situation wherein there is an excess of communication at a given time, as teams in various construction sectors take measures and actions and it is necessary to engage in communication [21]. Communicating can include conversing, listening, gathering data and information using various types of media, ranging from electronic to manual means of procurement [22]. 
Xie et al. [10] conducted studies that confirmed the significance of communication in the construction process. In this survey, the respondents were composed of representatives of design practices and construction companies with a yearly turnover of at least 50 million pounds. Over half of the respondents (51\%) pointed to the criticality of good communication within construction project participant teams. At the same time, a majority of respondents $(80 \%)$ noted the positive contribution of communication between teams of designers and contractors on the construction process. The authors of the study also asked respondents to list and order communication parameters that affect the effectiveness of design and building structures. The results clearly indicated that precision and completeness of information were the most critical variables. Punctuality and understanding received slightly lower ratings. Barriers and procedures were less important to the respondents. The authors of [10] identified problems in communication in respect to variables identified by the respondents, concluding that communication skills are equally important to professional engineers as engineering and academic abilities. Referencing a review of the literature, they argued that precise information must be supplied at every stage of design [23], as a substantial amount of imprecise information within construction projects resulted from poor coordination and poor communication skills [3,8]. According to Higgin et al. [24], Guevara et al. [5], Newton [3] and Thomas et al. [8], information required by project participants that refers to the design, schedules, regulations and technologies is often not available on time. As the results of the study by Xie et al. [10] have shown, the majority of respondents $(80 \%)$ and their organisations experienced the problem of imprecise information and $90 \%$ of respondents and their organisation often received information too late during the process of design and construction. While reviewing the process of team communication in a construction project, Higgin et al. [24] and Wallace [25] suggested that communication was inappropriate and that there was a lack of continuous interaction between participants during early stages of design. A lack of information becomes the primary source of conflicts within the team over the subsequent stages of design and construction. Communication within a team should ensure access to information to all members who need it. Insufficient or excessive information was also seen as detrimental [26].

Gorse et al. [27] noted that the construction sector is linked with communication problems that develop at the point of contact between key specialists. All stages of construction are based on professionals who communicate appropriate and critical information concerning the project so as to meet client demands. The design of a structure is rarely complete prior to the start of construction, and as the design develops, so does the demand for information. The prevalent practice of completing construction as quickly as possible means that detailed designs are completed during construction. Due to the limited amount of time, it is essential that design and structural problems are identified as quickly as possible. Failing to identify missing information or erroneous or conflicting information causes delays. It is critical that communication be effective, ensuring the proper understanding and processing of information so that the process can be performed effectively. According to the authors of [27], selecting the communication medium that best suits the solving of a given problem is an essential aspect of effective communication. In their studies, they concluded that face-to-face communication was the best suited for this. In this case, when one specialist tries to explain a problem, they can see when they are not understood by the other person. When information is sent via text or graphics in the form of mail, fax or e-mail, one is unable to check whether they have been understood. This can lead to uncertainty, misunderstandings or errors. The lack of feedback multiplies communication problems.

Dawood et al. [28] noted the high fragmentation of the construction sector when compared to other manufacturing sectors, which significantly affects performance. The authors observed that despite there being numerous studies, it was difficult to formalise the process of communication and information exchange within the construction process without affecting its quality. According to Dawood et al. [28], effective means of communication that support the project manager were listed as one of the initial conditions of improving performance in the construction sector. The authors claimed that when information flow is properly coordinated, the construction project becomes more effective and satisfies client needs better. Other authors [29-33] also pointed to the need to improve the effectiveness of 
communication between individuals and groups so as to aid performance increases in construction projects. Cook et al. [34] argued that successful projects were characterised by open information exchange and good communication between construction project teams. They also demonstrated that projects that experienced problems in the process of communication had problems with carrying out construction work. Gushgari et al. [35] performed survey studies among 500 construction companies in the United States with the aim to determine key skills required of project managers. Communication was reported to be the most important skill associated with long-term profitability. The ability to "listen" and to "manage projects" placed second and third, respectively. Zakeri et al. [36] performed a survey among construction workers who pointed to poor communication as one of the problems encountered during performing construction work, which led to workmanship problems. The study by Betney [37] showed that inefficient communication is one of the causes of structural errors.

Communication in construction projects is one of the key elements discussed in the literature on partnering in construction. Chan et al. [38], when pointing to the five key factors of success for partnering in construction, listed communication as a critical factor. $\mathrm{Ng}$ et al. [39] identified the lack of open communication as the main reason for the failure of partnering in construction. According to Cheng et al. [40], effective communication enables the sharing of visions and ideas, which leads to less misunderstanding and aids in building trust between construction partners. Meng [41] noted the fact that effective communication requires mutual trust, but mutual trust cannot replace communication. Despite the existence of trust between partners, one should still stress communication skills. Compared to performance indicators like time and cost, the author concluded that communication and trust do not overlap, although they are interlinked. Meng [41] indicated that the measures of construction project performance were its time, cost and quality, as completing a project on time, within budget and up to the intended quality standard was commonly seen as the three key aims of project success. Poor performance carried over to delays, extra costs and quality defects. To prove these assumptions, the author performed a survey study on a group of 105 construction sector practitioners from Great Britain. The results indicated that: (i) it was possible to avoid delays by improving cooperation, (ii) it was possible to avoid extra costs by effective communication and efficient problem solving, (iii) the occurrence of quality defects can be reduced via establishing effective problem-solving mechanisms and open communication concerning improving workmanship quality. To improve performance, the author suggested monthly review meetings, during which parties could improve communication, exchange information about cost and discuss options concerning the solving of emergent problems. The study concluded by stating that the problem of poor performance could be solved to some degree by improving relations and communication between the parties of a construction project. Radziszewska-Zielina et al. pointed to communication as being a key factor in partnering relations across many publications [42-45].

A considerable portion of studies concerning communication in the construction sector focuses on supporting it via information technology systems. Effective team communication in the design of buildings is becoming increasingly important due to the rising technical and organisational complexity of construction projects. The development and application of information systems that support communication is seen as one of the means of improving the performance of design teams and contractors [46]. Den Otter et al. [47] noted that communication within a design team depends on each member's communication activities and the ability of managers to facilitate, stimulate and motivate team members. In their studies, they focused on determining the effectiveness of using IT tools in communication within design teams and the strategies of using said tools. They observed that available means of communication should be used in a balanced manner and interaction with the aim of stimulating progress in design should depend on the design phase, as the time allotted to design is often limited and design team members can each work on several projects that are in varying stages of advancement at a given time. Due to the use of different communication tools by the team, communication can become ineffective without clear guidelines from management and the engagement of all team members. The authors of [47] investigated how important it was for the support system 
to be a properly constructed suite, arguing that an improper information updating system caused by poorly registered alterations and excess information can slow the progress of work on a technical design and on executing construction and negatively impact project performance. Furthermore, it can increase the number of design errors (and therefore costs).

When Polish studies of management in construction are concerned, the subject of communication is still rarely discussed. Scholars do acknowledge the need to explore the subject, however. Jelonek et al. [48] performed studies of high-level and middle management personnel within 23 construction companies in Poland. They demonstrated that the highest maturity of construction project management was present in areas of knowledge focusing on cost and time management. The lowest construction project management maturity was present in areas of knowledge associated with risk management and communication management. They noted that guidelines for company development aimed at increasing construction process performance should include the management level so as to obtain optimal solutions. Dubas et al. [49] noted that communication problems were an important problem in construction due to their direct impact on work quality. They pointed to a need for computer aided solutions so as to improve information transfer between construction project participants. They suggested developing a program that could simplify communication and improve information sharing performance during construction and during the transitional phase between the final stage of construction work and the initial occupancy stage. The lack of effective communication between project participants was indicated by Radziszewska-Zielina et al. [50] as the cause of problems during construction project execution in the centre of urban agglomerations. The authors of [51] also pointed out the difficult flow of information and documentation during the execution of such projects due to their specificity. The subject of communication between construction project participants under Polish conditions was discussed at length by Śladowski et al. [52]. The authors of [52] explored self-organising networks of communication between project participants during project execution. They demonstrated that communication within a self-organising network of project participants can significantly differ from the established form of communication defined by organisations. By using social network analysis (SNA), they discovered various irregularities in communication. They also noted the significance of monitoring communication over the entire cycle of project execution due to its dynamic character. They also presented the need to develop effective methods of optimising and supporting possible management staff interventions into the structure of such networks with the aim of more effectively conducting construction projects and limiting communication costs. Going further, in another paper, Radziszewska-Zielina et al. [53] proposed an optimisation approach to planning management staff interventions with the aim of improving communication within a network of construction project participants while accounting for various constraints, including the costs of communication. To perform the optimisation, the authors of [53] proposed a heuristic method. This method was presented on the example of an actual construction project involving the building of a housing complex. Input data for the analysis were defined on the basis of survey studies performed among project participants, which allowed the identification of their actual communication that took on the form of a self-organising information flow network. Based on a structural analysis, the authors identified irregularities in communication between the participants of this project. By applying the optimisation method, they demonstrated the potential for improving the effectiveness of communication between the participants of the project in question.

Table 1 presents a review of the literature, divided into factors where communication in the construction industry is important. Figure 1 presents the number of studies and publications that explored communication in the construction industry in the last 30 years. 
Table 1. Factors where communication in construction plays a significant role. Original work.

\begin{tabular}{|c|c|}
\hline \multicolumn{2}{|r|}{ Communication in Construction } \\
\hline Factors & Authors \\
\hline Effectiveness & $\begin{array}{l}\text { Austin et al., (1993) [54]; Hill (1995) [30]; Azam et al., (1998) [29]; Yap and Skitmore (2020) [55]; } \\
\text { Shirazi and Hampson (1998) [56]; Swaffield (1998) [31]; Swan et al. (2001) [32]; Mutti and Hughes (2001) [33]; } \\
\text { Gushgari et al., (1997) [35]; Zakeri et al. (1996) [36]; Higgin and Jessop (1965) [24]; Guevara and Boyer } \\
\text { (1981) [5]; Cheung, Liu and Yam (2013) [57]; Meng (2012) [41]; Dawood, Akinsola and Hobbs (2002) [28]; } \\
\text { Aiyewalehinmi (2013) [58]; Chiu (2002) [59]; Xie, Thrope and Baldwin (2000) [10]; Zhang et al., (2018) [60]; } \\
\text { Chinowsky, Taylor and Di Marco (2011) [61]; Hossain (2009) [62]; Pryke et al. (2018) [63]; } \\
\text { Gardounis, Chong and Wang (2017) [64]; Sladowski, Radziszewska-Zielina and Kania (2018) [52]; } \\
\text { Radziszewska-Zielina et al. (2019) [53]; Jafari et al. (2020) [65]. }\end{array}$ \\
\hline Time, Cost, Quality & $\begin{array}{c}\text { Thamhain and Wilemon (1986) [66]; Sonnenwald (1996) [4]; Thomas et al. (1998) [8]; } \\
\text { Olanrewaju et al. (2017) [67]; Cheung, Liu and Yam (2013) [57]; Meng (2012) [41]; } \\
\text { Berenger and Justus (2016) [68]; Chiu (2002) [59]; Xie, Thrope and Baldwin (2000) [10]; } \\
\text { Bowen and Edwards (1996) [69]; Zulch (2014) [11]; Jelonek, Nowakowska-Grunt and Ziora (2014) [48]; } \\
\text { Preece and Stocking (1999) [70]; Abudayyeh (1994) [71]; Harback et al. (1994) [72]; } \\
\text { De Vilbiss and Leonard (2000) [73]; Black et al. (2000) [74]; Gamil and Rahman (2017) [75]; } \\
\text { Gorse, Emmitt and Lowis (1999) [27]; Hoezen, Reymen and Dewulf (2006) [12]; Emmitt and Gorse (2007) [76]; } \\
\text { Dainty, Moore and Murray (2006) [22]; Muller and Turner (2005) [77]; Malisiovas and Song (2014) [78]; } \\
\text { Hossain (2009) [62], Pryke et al. (2018) [63]; Radziszewska-Zielina et al. (2019) [53]; Jafari et al. (2020) [65]. }\end{array}$ \\
\hline Delays & $\begin{array}{l}\text { Berenger and Justus (2016) [68]; Gamil and Rahman (2017) [75]; Gorse, Emmitt and Lowis (1999) [27]; } \\
\text { Hoezen, Reymen and Dewulf (2006) [12]; Larsen et al. (2015) [79]; Liu et al. (2007) [80]; } \\
\text { Assaf and A-Hejji (2006) [81]; Zidane and Andersen (2018) [82]; Durdyev and Hossein (2019) [83]; } \\
\text { Leśniak and Plebankiewicz (2010) [84]; Malisiovas, Song (2014) [78]. }\end{array}$ \\
\hline Redesign And Rework & $\begin{array}{l}\text { Cook and Pasquire (2001) [34]; Love et al. (1999a, 1999b) [85,86]; Fayek et al. (2003) [87]; } \\
\text { Hwang et al. (2009) [88]; Boon Hui, Abdul-Rahman and Chen (2017) [89]; Kamalirad et al. (2017) [90]; } \\
\text { Safapour, Kermanshachi and Taneja (2019) [91]; Safapour and Kermanshachi (2019) [92]; } \\
\text { Calvert et al. (1995) [93]; Harvey and Ashworth (1997) [94]; Gorse (2002) [95]. }\end{array}$ \\
\hline Workplace Health And Safety & $\begin{array}{c}\text { Preece and Stocking (1999) [70]; Pandit et al. (2020) [96]; Albert and Hallowell (2017) [97]; } \\
\text { Alsamadani, Hallowell and Javernick-Will (2013) [98]; Cigularov, Chen and Rosecranceb (2010) [99]; } \\
\text { Kines et al., (2010) [100]; Liao et al. (2014) [101]; Kaskutas et al. (2013) [102]; Tutt et al. (2013) [103]; } \\
\text { Hofmann and Stetzer (1998) [104]; Pandit et al. (2019) [105]; Ghodrati, Yiu and Wilkinson (2018) [106]; } \\
\text { Hoła and Polak (2012) [107]. }\end{array}$ \\
\hline Partnering & $\begin{array}{l}\text { CII (1991) [108]; Cowan et al. (1992) [109]; Uher (1999) [110]; Cheng and Li (2002) [111]; } \\
\text { Abudayyeh (1994) [71]; Harback et al. (1994) [72]; De Vilbiss and Leonard (2000) [73]; Black et al. (2000) [74]; } \\
\text { Chan et al. (2004) [38]; Ng et al. (2002) [39]; Cheng et al. (2000) [40]; Meng (2012) [41]; Xie et al. (2010) [112]; } \\
\text { Radziszewska-Zielina and Szewczyk (2014, 2015. 2016) [43-45]; Chan et al. (2006) [113]; } \\
\text { Szewczyk and Radziszewska-Zielina (2020) [114]. }\end{array}$ \\
\hline
\end{tabular}

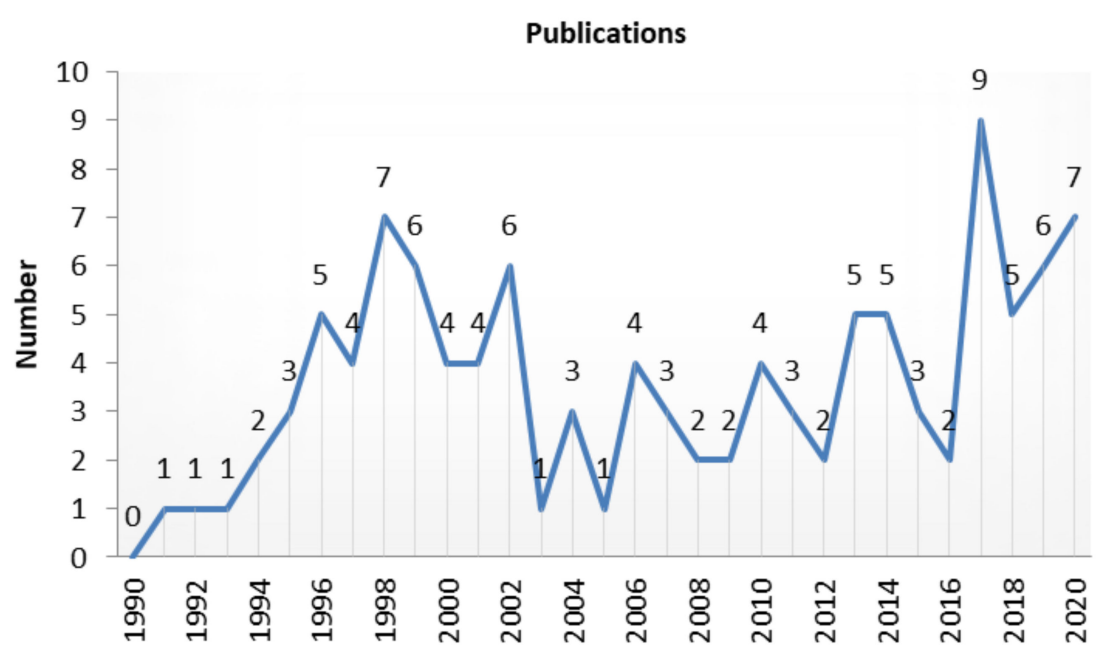

Figure 1. Number of publications on communication in the construction industry between 1990 and 2020. Original work.

As the review of the literature presented above has shown, the problem of information flow in construction projects requires further study, with the objective being to supplement the current state of the art and structure the subject matter. In addition, one should note the fact that most studies concerning communication in construction projects and its improvement are focused on the design stage, while there are few studies of communication during the construction stage. To achieve this goal, the authors of this paper address the gap in global research by presenting a survey study performed in Poland on a group of 160 practicing construction project participants. Based on the results of the study, 
the authors analysed the need to develop tools that can support effective communication between construction project participants.

\subsection{Characteristics of Construction Industry Practitioners}

The study was performed on a purposive sample. The survey was addressed to engineers who work in the construction sector. The participants were persons involved in every stage of a construction project, with many years of experience in construction (Figure 2), such as: contract managers, directors, managers and construction engineers, works managers, construction company owners, designers, developers and developer supervision inspectors, cost assessment specialists, workplace health and safety coordinators, Building Information Modeling (BIM) coordinators (Figure 3).

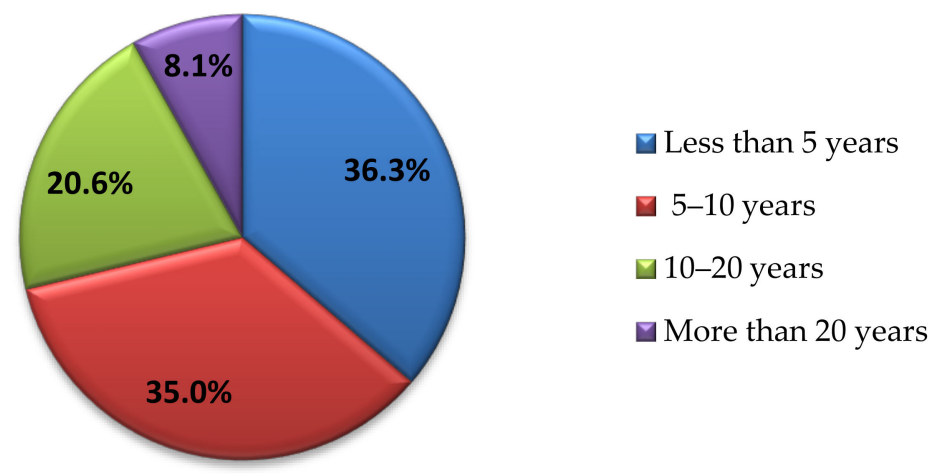

Figure 2. Work experience in the construction sector. Original work.

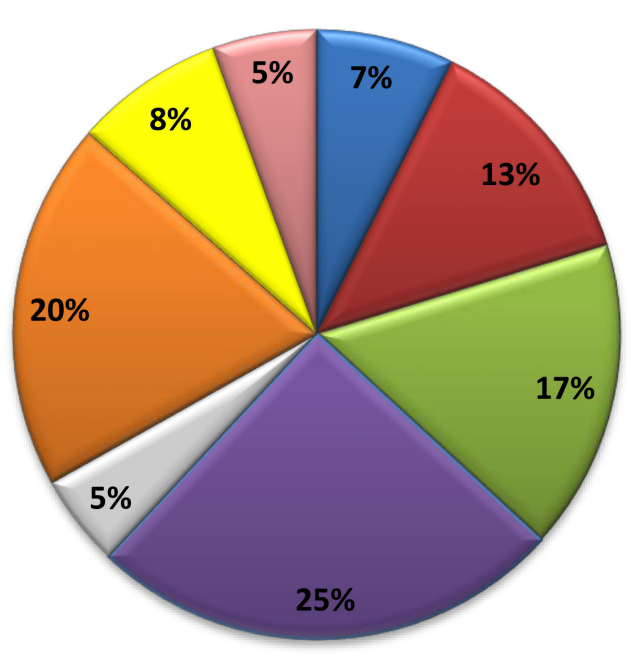

- Contract director/manager

曰 Site manager

$\square$ Works manager

$\square$ Construction engineer

$\square$ Construction company owner/director/chairperson $\square$ Designer

$\square$ Developer/Developer supervision inspector $\square$ Others (Contract manager assistant, Designer assistant, Workplace health and safety coordinator, Cost assessment specialists, Technical office director, BIM coordinator, Developer supervision inspector assistant)

Figure 3. Percentage share of respondents within the sample by the function they performed in the project. Original work.

The respondents were asked to disclose whether they took part in construction projects with a value that exceeded 50 million polish zloty (PLN) (Figure 4). More than half of the respondents (56.3\%) took part in such projects. 


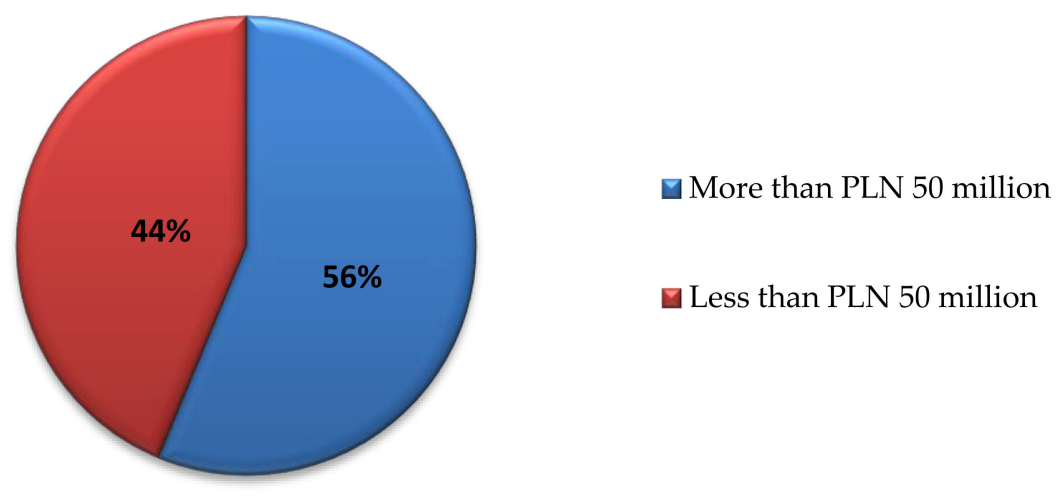

Figure 4. Participation in construction projects with a value exceeding PLN 50 million. Original work.

Examples of projects that the respondents had participated in included the largest Polish projects of the last decade, e.g., Varso Tower, the National Stadium in Warsaw, the Unity Center complex (The Skeletor) in Krakow, the Passenger Terminal of the Lech Wałęsa Airport in Gdańsk, the A1 Highway, the Jaworzno Electrical Power and Heating Plant and the Electric Power Plant in Opole, the Złota 44 building in Warsaw, the High Five complex in Krakow and the Łódź Fabryczna train station. In terms of project type, the respondents participated in most types of construction projects: the largest multibuilding housing complexes in Poland, state-of-the-art office buildings, railway, highway and bridge projects, manufacturing facilities, sports halls, stadiums, airports, industrial buildings, logistics centres, shopping galleries, hotels, hydrotechnical structures, public buildings, educational buildings and single-family houses. A subgroup of the respondents also participated in projects outside of Poland, e.g., in Great Britain, Germany or Slovakia. Concerning all of the aspects discussed above and the size of the sample, the results can be considered notable.

\subsection{General Information about Communication and Information Flow between Construction Project Participants}

Based on the literature review presented earlier in the paper, it can be stated that communication between construction project participants is critical. This statement was supported by $98.8 \%$ of the surveyed practitioners. The experts pointed to many characteristics that justified the significance of communication in construction projects, which has been discussed below. Most experts focused on the link between effective communication and a positive impact on completion time, cost efficiency and workmanship quality (Figure 5) and the impact of the lack of or an insufficient amount of communication on the occurrence of defects, and, as a result, delays and additional costs. The respondents also noted the significant number of construction project participants and that all parties worked towards a common goal and indicated that skilful communication was essential and critical to accomplish this.

Theoretically, each has the same goal but different priorities, work style and experience. Communication is necessary in order to formulate the best solutions and make optimal use of human resources (e.g., creativity of participants). The respondents also claimed that the correct execution of any construction project is based on knowledge, which is a collection of information provided in the right way, to the right people, and at the right time. Thus, a lack of information results in lack of required knowledge, which generates unnecessary/unforeseen problems and costs. High project complexity requires proper information management on the site.

The respondents indicated a need to approve design and technological solutions and to synchronise tasks. Fast-paced work requires coordination between many overlapping industries. Lack of information flow reduces the pace and increases the risk of budget error. A considerable number of respondents pointed out the importance of the exchange of information in project decision-making. This may concern, for example, approval of materials, changes in documentation, acceptance, invoicing, work schedule, the involvement of appropriate human and equipment forces. All elements have 
a strong impact on the final effect-i.e., timely completion of works within the assumed quality and budget.

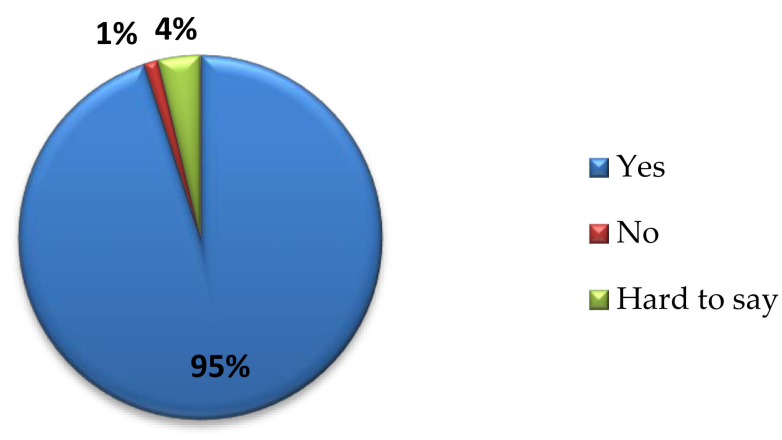

Figure 5. Distribution of answers to the question whether the experts thought that more effective communication between construction project participants enabled the project to succeed and whether it positively affected project duration, cost, quality and workplace health and safety conditions. Original work.

The amount of time spent on communication also shows how essential it is during the carrying out of construction projects. It turned out that almost $70 \%$ of respondents spent over $50 \%$ of their working hours on communication (Figure 6). The amount of time spent on communication also differed depending on the years of experience in construction. In the case of experts with less than 5 years of experience, $37.5 \%$ of respondents spent $25 \%$ of their time on communication and similarly, $37.5 \%$ of respondents pointed to $50 \%$ of their work time being spent on communication. In the case of experts with 5 to 10 years of experience, $42 \%$ reported they spent around $50 \%$ of their work time on communication. Experts with 10 to 20 years of experience in construction also mostly reported spending $50 \%$ of their work time on communication ( $43 \%$ of this group). However, in contrast to the previous two groups, the answer pointing to $75 \%$ of time spent was the second most frequently picked answer ( $30 \%$ of respondents). The group with the greatest amount of experience displayed similar results as the previous one.

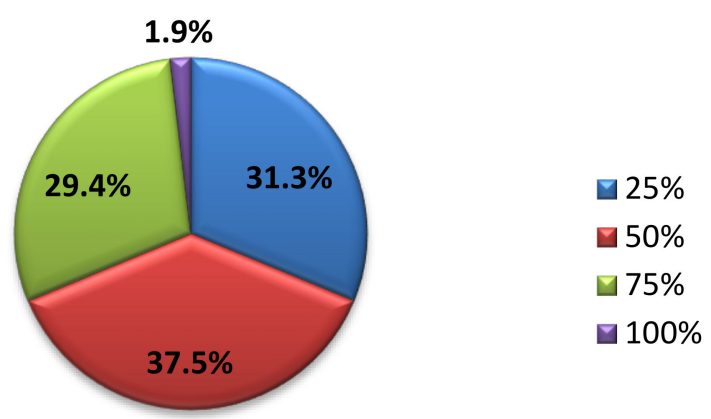

Figure 6. Survey result showing how much time the experts spent on communication (making phone calls, engaging in fact-to-face contact, writing e-mails) over a single working day. Original work.

It can be concluded that improving communication effectiveness could help save precious time and allow one to focus on other tasks.

\subsection{Opinions about Problems in the Carrying Out of Construction Projects with Respect to a Lack of Effective Communication}

Due to the amount of problems that can occur during the carrying out of larger construction project, it is critical to share information instead of merely focusing on individual tasks. New, previously unforeseen circumstances appear throughout the entirety of a project's duration- 
circumstances that modify work time, conditions and even force the introduction of design changes, which requires all parties to react swiftly so as to effectively solve problems. Respondents cited specific examples concerning the importance of based on completed projects. Examples included the need to reinforce soil; building services clashes or the discovery of unidentified infrastructure on the site, quick action needs to be taken. Schedules leave little room for error and problems must be resolved quickly. The smooth flow of information between the Contractor, Subcontractor, Designer, and Developer can allow for new problem-solving ideas to be presented that can make work much easier.

The respondents claimed that a lack of communication or an insufficient amount thereof generates numerous problems, errors and costs, in addition to a lack of Developer satisfaction during the late phase of the project. However, they also noted that an excess of communication can also negatively affect the construction process. Several positive aspects that effective communication can impact were also listed. It was reported to shorten design time and to enable the avoidance of numerous misunderstandings that result in the necessity to introduce design changes that generate additional monetary cost. Proper communication during the carrying out of construction work results in everyone being aware of any decisions and knowing how to interpret them. This makes it possible to avoid errors and corrections which can considerably affect the cost and pace of work. It also allows everyone to save time. The respondents were of the opinion that information flow guarantees effective work towards a common goal. When that goal is reached, the expectations of the developer are met. At the same time, the entire process can be more effective and take a smaller amount of time, saving all parties from a lot of needless frustration. The effectiveness of communication was also stressed. The method of communication determines the success of a project. The better and the more precise communication is, the better and more precise the realisation of a construction project. Some respondents even went as far as to state that it is impossible to successfully build anything without effective communication.

The amount and quality of information transferred and the manner of communication during the carrying out of a construction project are not sufficient to effectively perform construction projects. As many as $95 \%$ of the respondents stated that the process of communication during previously completed projects could have been better. They also reported the share of completed projects during which the communication process could have been better. The largest group of respondents $(17.5 \%)$ reported that this applied to half of the projects, while only a slightly smaller number of respondents $(16.9 \%)$ pointed to this applying to $70 \%$ of projects, and $13.1 \%$ of the respondents pointed to $100 \%$ of projects, which was the third most frequently selected option. The results will be presented on the chart shown in Figure 7. The experts in the group with less than 5 years of experience typically reported $70 \%$ and $80 \%$ of projects that required improvement in communication. For experts with 5 to 10 years of experience, this was $70 \%$ and $100 \%$ of projects, respectively. In the case of experts with 10 to 20 years of experience, $50 \%$ of the projects they had worked on should have had better communication, while experts with more than 20 years of experience typically reported $100 \%$ of projects.

Most studies concerning communication in the construction process and its improvement focus on the design stage, while there is a lack of studies of the construction phase. According to the survey study presented herein, under Polish conditions (Figure 8), most communication and information flow problems appear during the construction phase of a project, during project handover, and at the start of construction work. Therefore, managing a communication network by planning and monitoring it throughout the entire cycle of a construction project should become the main focus because of its dynamic character. 


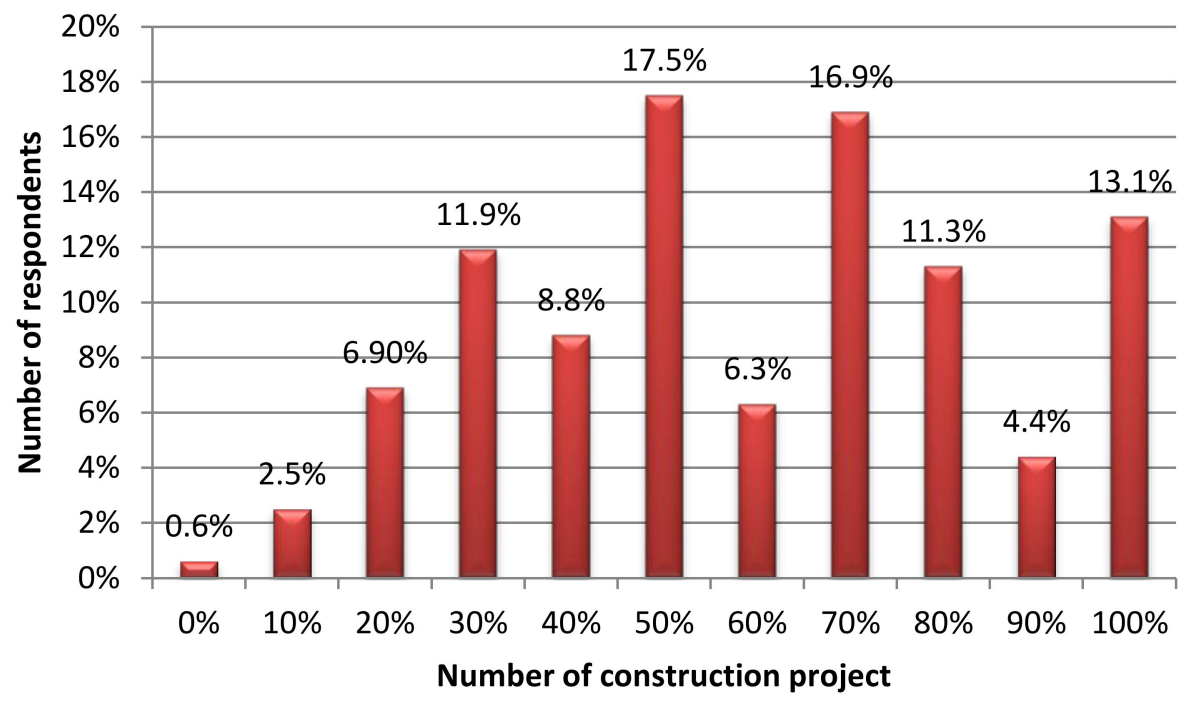

Figure 7. Distribution of answers to the question concerning the percentage of projects the experts had worked on that could have benefitted from a better communication process. Original work.

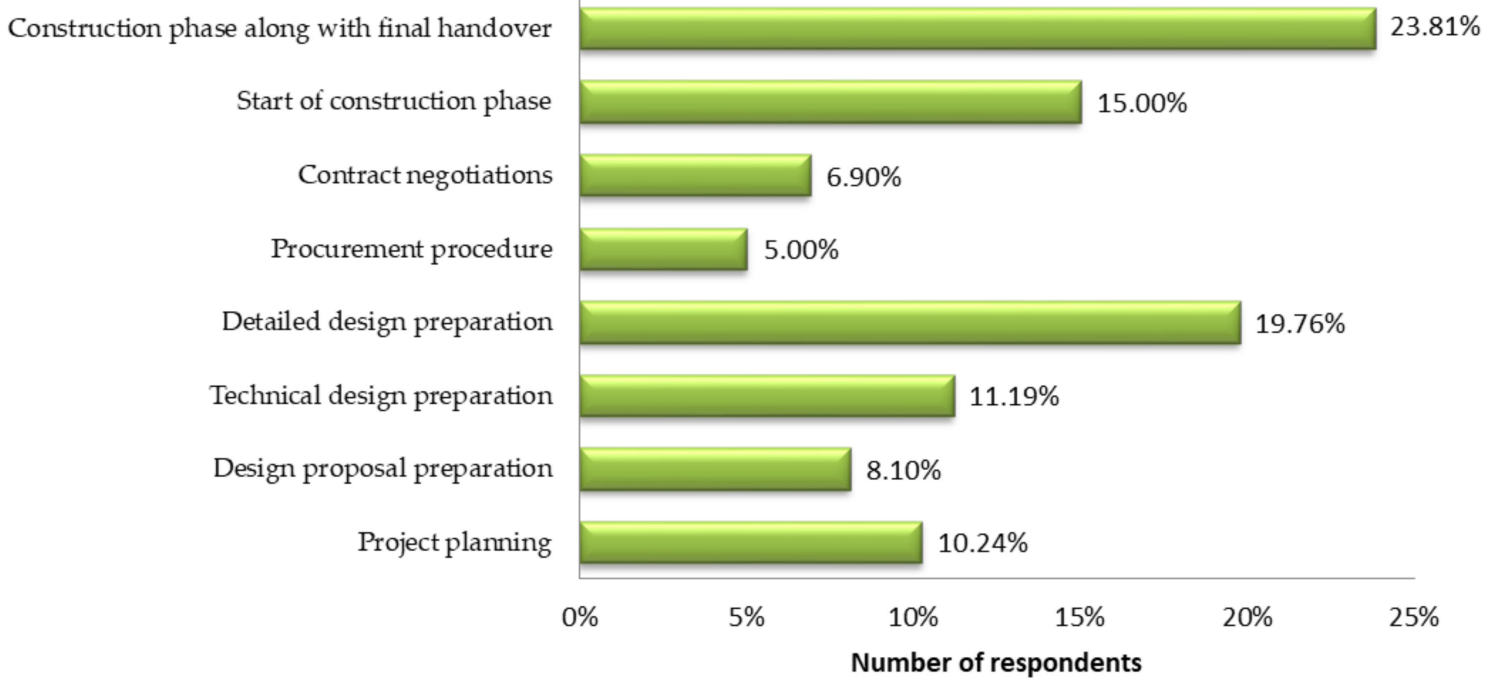

Figure 8. Distribution of answers to the question concerning the construction project stage that features the most problems with communication and information flow between project participants. Original work.

Numerous respondent opinions and literature reviews were found to confirm the relationship between poor communication and problems during the design and construction stages. Therefore, improving information flow could lower the amount of emerging problems.

\subsection{Opinions about the Impact of Communication on the Success of Construction Projects}

The success of a construction project is typically determined on the basis of meeting the characteristics of the so-called 'golden triangle': time, cost and quality. Carrying out a construction project within a specific timeframe, within budget and up to a certain quality standard is considered a success. Many authors also explore what affects attaining this success by searching for success factors [115-117]. Chua et al. [118], using the AHP method, presented a hierarchical model of the success of a construction project and identified sixty-seven relevant success factors (four of which were related to communication: formal design communication, informal design communication, formal construction communication, informal construction communication). The indicated factors have been 
grouped into four main project aspects, namely, project characteristics, contractual arrangements, project participants and interactive processes. Chan et al. [119] established a framework for measuring the success of construction projects based on a literature review. They identified a set of Key Performance Indicators (KPIs), which consist of objective (eight factors) and subjective (six factors) indicators. Whereas, Chen et al. [120] identified sixty-two success factors for construction projects on the basis of a literature review and then limited them to forty-six critical success factors as part of discussions with experts. Using the Structural Equation Model (SEM), they investigated the interdependencies between critical success factors and created a hypothetical model of critical success factor interdependencies for construction projects. Sanvido et al. [121] derived the factors which determine the success of the construction process and then tested them on sixteen projects showing correlations between the indicated factors and the success of the project under construction. Yang et al. [122] identified critical success factors related to stakeholder management in construction projects. As a result of a literature review, fifteen critical success factors were identified and discussed during interviews and a pilot programme with construction professionals. The three highest-rated factors in this respect were "managing stakeholders with social responsibilities," "assessing the stakeholders' needs and constraints to the project," and "communicating with stakeholders properly and frequently."

Many success factors were repeated in the cited studies, for example: the developer's financial liquidity, realistic commitments and clear goals, experience and competence of the project participants, communication, risk identification, equipment facilities. There were also exceptional factors such as trade unions; riots, revolution and war; trade sanctions and embargoes.

The authors of this study have used the factors indicated by Knotten et al. [15], which examined the success factors for construction project management, to characterise success factors for Polish construction projects and in their review article. Based on the analysed literature, nine success factors that had been most frequently mentioned by the researchers were characterised (Table 2). They were applied in the survey study to verify the impact of communication and information flow on construction project success.

Table 2. Overview of factors that affect the success of construction projects. Original work based on [15].

Success Factors
Developer (a developer that properly presents their requirements and has an appropriate budget)
Communication (project coordination, negotiations, design solutions, network of linkages between participants)
Decisiveness (making decisions on time)
Workplace health and safety (procedures ensuring safe working conditions during a construction project)
Knowledge management (possession of experienced and well-qualified management cadre and sharing knowledge
appropriately during the project)
Construction crew and equipment performance (possessing experienced and highly qualified construction crews and
proper machinery and equipment during the project)
Planning (planning the entire process of the construction project, cost planning, time planning, quality planning,
controlling changes)
Risk management (identification, assessment, monitoring and minimization of risk occurring during the execution of
the project; minimization of the effects of adverse events)
Team management (managing management, construction crew and subcontractor personnel, delegating work,
involvement in executing the project)

As part of the study, the respondents were asked to sort these factors, from those that had the highest impact on a construction project's success to those that had the lowest impact, which is been presented in Figure 9. The respondents pointed to communication having the highest impact, which underscores the weight of the matter. 


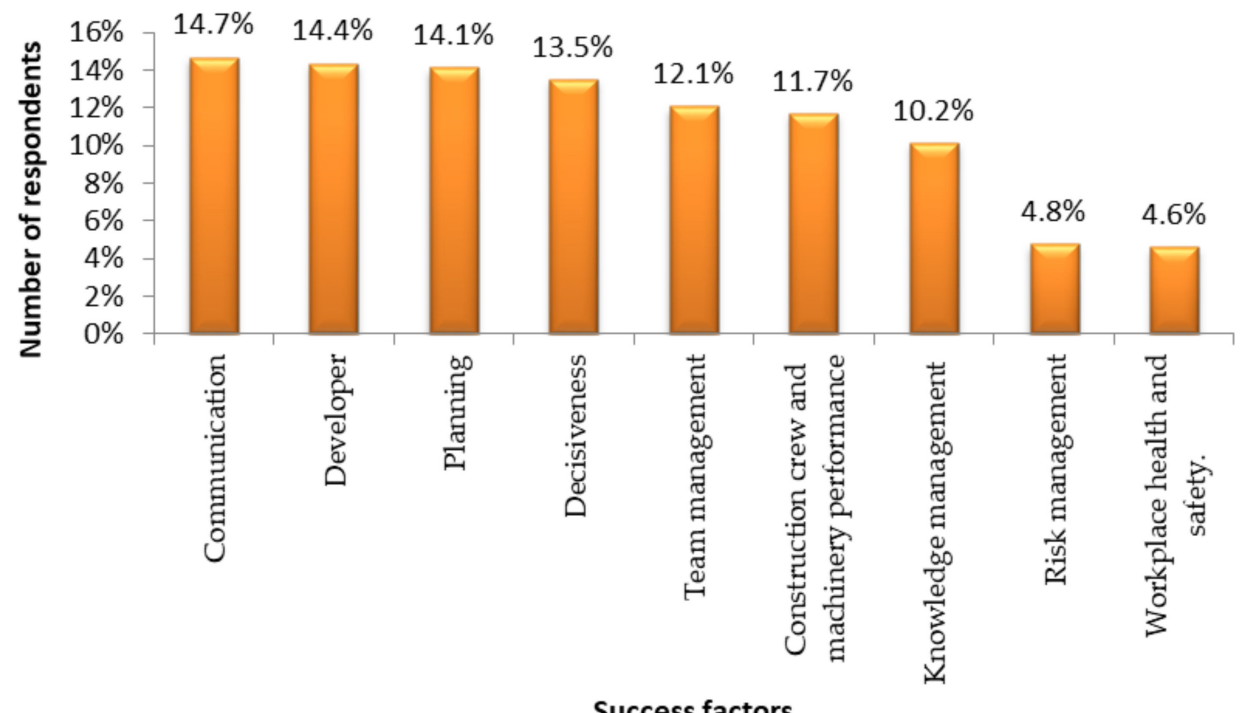

Figure 9. Distribution of answers to the question as to which of the presented factors had the highest impact on a construction project's success. Original work.

\subsection{Opinions about the Cost of Communication}

The respondents were asked whether they thought that communication and information flow during a construction project generates costs. As many as $69 \%$ of the respondents agreed with the statement that communication generates costs. What is interesting is that for the group that worked on projects worth in excess of PLN 50 million, the generation of cost by communication was confirmed by $69 \%$ of respondents, while in the second group this was also the answer of $69 \%$ of respondents. It can therefore be stated that despite differences in project budget, communication cost was equally significant in the cost of the entire construction project.

The respondents noted that properly conducted communication can save a project from greater costs caused by other problems. Properly organising communication has its cost, but the lack of communication would cost more. One cost of communication mentioned by respondents was the time that project participants spent on communication and meetings, and, as a result, the cost of their salaries that is factored into the overall construction cost; the knowledge that must be procured, i.e., the project plan, design documentation and other types of information necessary to complete tasks. If this knowledge is accessible and prepared well, it can lower project cost. However, it was observed that communication costs are difficult to define and are not typically featured as an item in a construction project's cost schedule.

\subsection{Opinions about the Need to Develop a Tool (Digital System), which Could Aid Construction Project Managers in the Optimal Controlling of Communication between Project Participants}

Based on the literature review, the authors observed the oft-reported need to optimise information flow within construction projects. Existing formal organisational structures and current communication procedures often do not account for many important factors that characterise construction projects, i.e., their temporary character and dynamic structure. The authors became interested in identifying the possibility of supporting information flow control in an optimal manner while using computer software.

The respondents were asked also whether any methods or programs that improve the effectiveness of communication between project participants were used during the projects they had participated in previously. As many as $67 \%$ of respondents answered negatively. The remaining $33 \%$ of respondents were asked to identify these methods or programs. The answer given most often pointed to coordination meetings with the developer and subcontractors and internal meetings hosted by the contractor. The reports also listed communications media such as the telephone, e-mail, servers that provide 
access to documentation, applications that highlight the locations of defects, mobile text messaging applications and Google Drive. The respondents also identified numerous computer-aided design and documentation sharing systems. However, they did not list any programs that would optimally support communication management. Decision makers were also asked whether they saw a need to develop a support tool (an IT system) for controlling information flow and communication between construction project participants. As many as $67.5 \%$ of respondents saw the need for the development of such a tool and expressed interest in using possible future IT tools that could effectively aid in managing communication between construction project participants. Interest in such software was reported by $65 \%$ of experts in the group with 5 years of experience or less, while in the group with 5 to 10 and 10 to 20 years of experience, such interest was expressed by $67 \%$ of respondents. The greatest interest in a program that could aid information flow management in a construction project was shown by the most experienced group of practitioners, as $72 \%$ of respondents in this group expressed such interest.

Due to considerable interest in the issues of information flow within construction projects, as determined by a review of the literature, the demonstrated needs of practitioners, and the simultaneous lack of available studies on communication management support models dedicated to construction projects and the difficulty of adapting the existing models of information flow control in other branches of the economy, the authors are currently in the process of developing a model of control and monitoring of communication networks between construction project participants. It is necessary to take into account the unique and specific features of construction projects, such as their dynamic organisational structure (which constantly changes and adapts to achieve project objectives) and its temporariness. It is therefore important to monitor information flow throughout the entire project cycle. A conceptual diagram is presented in Figure 10. The authors propose an innovative approach to the application of metanetwork analysis to solve the indicated problem.

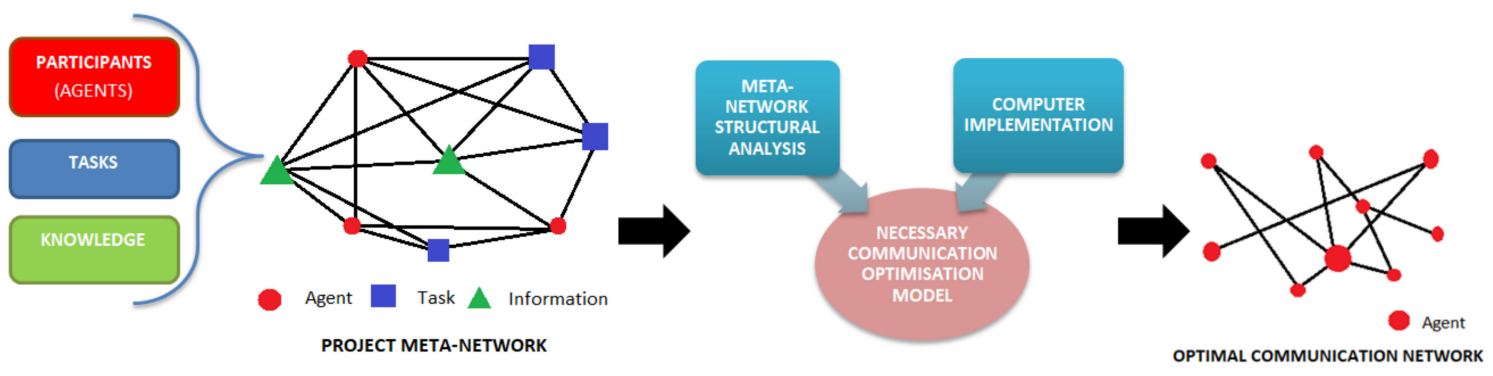

Figure 10. Conceptual diagram of the proposed communication optimisation model in a construction project. Original work.

\subsection{Respondent Opinion Concordance}

In order to acknowledge the parameter significance ratings concerning multiple-choice answers (Figures 7-9) as reliable, respondent concordance was verified using the Kendall concordance coefficient [16]. When correlations are present (several parameters receiving the same ratings) the concordance coefficient is expressed using Equation (1) [16],

$$
W=\frac{s}{s_{\max }-m T}=\frac{\sum_{j=1}^{p}\left(R_{j}-\frac{m(p+1)}{2}\right)^{2}}{\frac{1}{12} m^{2}\left(p^{3}-p\right)-m T}
$$

where pnumber of parameters, mnumber of respondents, $S$-degree of actual correlation between rankings, $S_{\text {max }}$ correlation degree for full ranking concordance, $R j$ sum of the degrees of parameter $j$ (Equation (2) [16]), T—correction accounting for ties (Equation (3) [16]).

$$
R_{j}=\sum_{i=1}^{m} a_{i j}
$$


where $a_{i j}$-rank of parameter $j$ (for $j=1,2, \ldots, \mathrm{p}$ ) calculated based on the preference of respondent $i$ (for $i=1,2, \ldots, \mathrm{m}$ ).

$$
\begin{gathered}
T=\sum_{i=1}^{m} T_{i} \\
T_{i}=\frac{1}{12} \sum_{k=1}^{K}\left(t_{k}^{3}-t_{k}\right)
\end{gathered}
$$

where $K$-the number of groups that have the same rank $(k=1,2, \ldots, K)$ in row $k, t_{k}$-number of identical tied ranks within a group.

The value of the concordance coefficient takes on a value between 0 and 1 , where 1 denotes full row concordance, while 0 denotes no concordance. The following interpretation of concordance degrees based on the value of this coefficient is proposed in the literature [123]:

- $\quad$ satisfactory, for a range of $0.20-0.40$,

- good, for a range of $0.41-0.60$,

- plus good, for a range of $0.61-0.80$,

- very good, for a range of $0.81-0.95$,

- $\quad$ perfect, for a range of $0.96-1.00$.

The authors of [124] observed that when the number of experts increases, the concordance value drops and becomes closer to 0 .

The authors performed a concordance coefficient statistical significance test using the chi-squared test. The null hypothesis $\left(\mathrm{H}_{0}\right)$ stating that there is a lack of correlation between the rows is rejected, as the value of $\chi_{r}^{2}$ (Equation (5)) is equal to or greater than $\chi_{\alpha}{ }^{2}$, which is the value read from chi-squared distribution tables for degrees of freedom equal to $\mathrm{df}=\mathrm{p}-1$ with a given significance level $\alpha$ [16] (a value of $\alpha=0.05$ was assumed):

$$
\chi_{r}^{2}=\frac{S}{\frac{1}{12} m p(p+1)-\frac{1}{p-1} T}
$$

Table 3 presents the results of respondent opinion verification. The results indicated a good and satisfactory level of concordance among respondents who took part in the survey. The null hypothesis can be rejected for all of the analysed parameters. The concordance of respondent opinions was

\begin{tabular}{|c|c|c|c|c|c|c|c|c|c|c|c|}
\hline $\begin{array}{l}\text { Parameter under } \\
\text { Analysis }\end{array}$ & $p$ & $m$ & $S$ & $T$ & $W$ & Interpretation & $x_{r}^{2}$ & $d f$ & $\alpha$ & $x_{\alpha}{ }^{2}$ & $\mathrm{H}_{0}$ \\
\hline $\begin{array}{l}\text { Number of projects } \\
\text { in need of better } \\
\text { communication }\end{array}$ & 11 & \multirow{3}{*}{160} & 296,986 & 13,200 & 0.422 & Good concordance degree & 674.968 & 10 & \multirow{3}{*}{0.05} & 18.3070 & Rejected \\
\hline $\begin{array}{c}\text { Stage when } \\
\text { communication } \\
\text { problems appear }\end{array}$ & 8 & & 300,533 . & 2224.5 & 0.418 & Good concordance degree & 467.965 & 7 & & 14.0671 & Rejected \\
\hline $\begin{array}{l}\text { Construction project } \\
\text { success factor }\end{array}$ & 9 & & 474,641 & 383 & 0.322 & Satisfactory concordance degree & 411.970 & 8 & & 15.5073 & Rejected \\
\hline
\end{tabular}
not accidental.

Table 3. Respondent opinion concordance verification results.

\subsection{Limitations of the Investigation}

As a result of the literature review and survey study on a group of practitioners, a considerable amount of valuable information on communication and information flow in construction projects was obtained. The results of the study are presented in graphical form in Figure 11. 


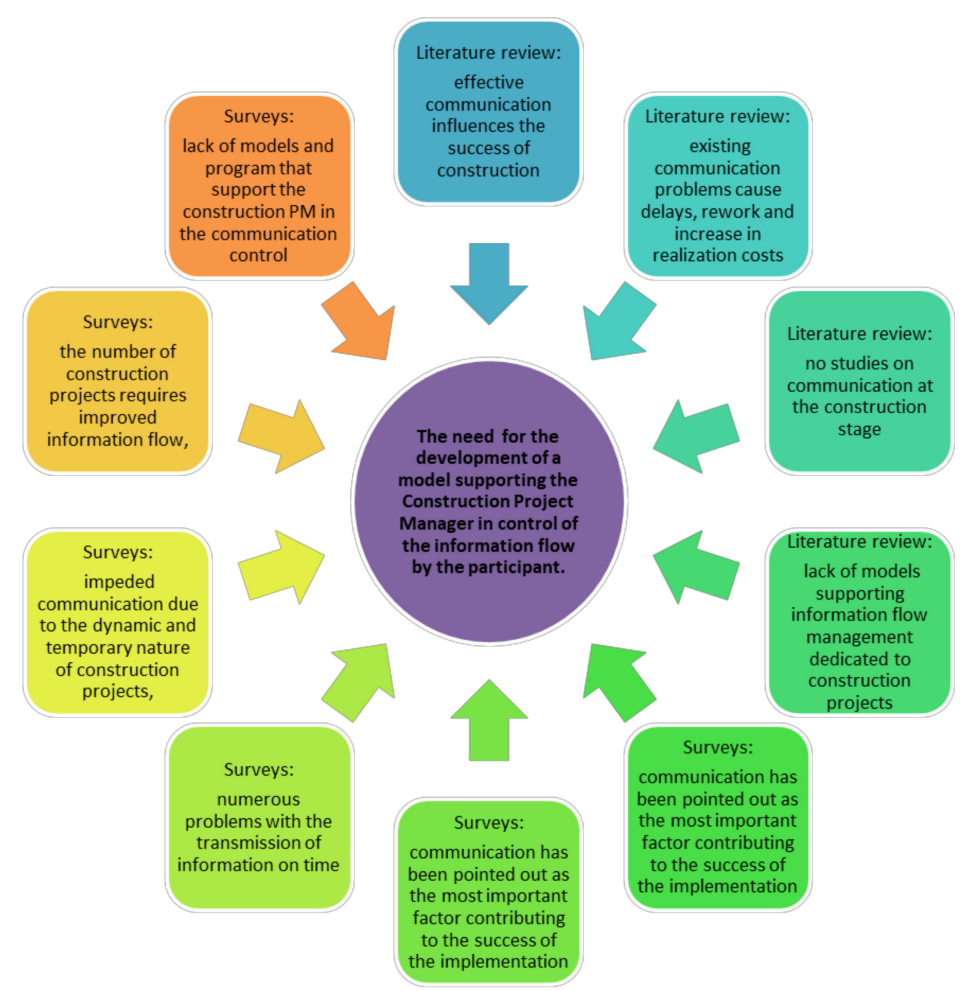

Figure 11. Diagram of the results of the literature study and the survey. Original work.

The research approach presented in the paper has limitations. They primarily stem from the research method employed in the study. The method used in the survey study, despite its popularity and the possibility of collecting the opinions of experts, is affected by a certain level of uncertainty due to the human factor. It is known that the data are subjective, which is why it was necessary to verify the concordance of respondent opinions to determine the reliability of responses and the possibility of drawing conclusions.

\section{Conclusions}

Based on the literature review and survey study performed by the authors, it can be concluded that communication between construction project participants is an essential matter. Many academic publications report the impact of communication and information flow on the so-called 'golden triangle': time, cost and quality. In the presented study, its respondents confirmed this under Polish conditions. At the same time, it was determined that effective communication significantly contributes to project success and was identified by experts as the most essential factor that affects achieving success in carrying out construction projects in Poland. Based on the information collected, the authors also demonstrated the effects of the lack of effective communication. It was indicated that communication was reported to be ineffective in the carrying out of construction projects in Poland, which leads to problems and, as a consequence, delays and additional costs. The results of the survey study performed among the community of Polish construction-sector practitioners can be generalised and seen as, at least in Central Europe, representative, as the data confirmed the conclusions of previous literature reviews and fills the research gap concerning the need for managing communication between project participants.

A significant number of academic publications discuss information flow during construction projects, but only focus on improving communication during the design stage. No studies on communication between project participants during the carrying out of construction projects were found. Such studies were expected by practitioners who took part in this study. This study supplements and extends the current state of knowledge on the impact of communication on construction project 
success, problems in construction projects and communication costs. The lack of tools that could support construction project managers in effectively controlling information flow between construction project participants was also demonstrated. The study also presents the needs and expectations of construction-sector practitioners in reference to possible future software that would aid in controlling and monitoring the network of communication between the participants of construction projects.

The direction of further studies should therefore focus on developing methods and tools and that support project managers in effectively and optimally controlling information flow in the context of achieving set goals. It is necessary to account for the unique and distinct features of construction projects, such as: their dynamic organisational structure (which constantly changes and adapts to work towards project goals) and its temporary character. The study on information flow should be developed with a focus on its different contexts, such as the design documentation, work schedule, workplace health and safety or financial settlements. It appears justified to work towards optimising the structure (which is typically identified in the literature as a network) of participants. It is necessary to determine the costs of communication between project participants, as the actual impact of effective communication on project cost is observable, yet difficult to measure.

The presented results confirm the need to develop the subject matter of the management of communication and information flow between construction project participants. Studies focusing on these needs and directions of further study shall be explored in separate papers by the authors.

Author Contributions: Conceptualization, E.K., E.R.-Z., G.Ś.; methodology, E.R.-Z.; formal analysis, E.K.; investigation, E.K.; writing—original draft preparation, E.K.; writing—review and editing, E.R.-Z., G.Ś.; visualization, E.K.; supervision, E.R.-Z., G.Ś.; project administration, E.K. All authors have read and agreed to the published version of the manuscript.

Funding: This research received no external funding.

Conflicts of Interest: The authors declare no conflict of interest.

\section{References}

1. Baldwin, A.N.; Austin, S.A.; Murray, M.A.P. Improving design management in the building industry. In The Design Productivity Debate; Duffy, A.H.B., Ed.; Springer: London, UK, 1998; pp. 255-267.

2. Austin, S.; Baldwin, A.; Newton, A. A data flow model to plan and manage the building design process. J. Eng. Des. 1996, 7, 3-24. [CrossRef]

3. Newton, A.J. The Planning and Management of Detailed Building Design. Ph.D. Thesis, Loughborough University, Loughborough, UK, 1995.

4. Sonnenwald, D.H. Communication roles that support collaboration during the design process. Des. Stud. 1996, 17, 277-299. [CrossRef]

5. Guevara, J.M.; Boyer, L.T. Communication problems within construction. J. Constr. Eng. 1981, 107, 552-557.

6. Anumba, C.J.; Evbuomwan, N.F.O. A taxonomy for communication facets in concurrent life-cycle design and construction. Comput. Aided Civ. Infrastruct. Eng. 1999, 14, 37-44. [CrossRef]

7. Knoop, W.G.; Breemen, E.J.J.V.; Vergeest, J.S.M.; Wiegers, T. Enhancing engineering performance through more intensive communication. In Proceedings of the Third ISPE International Conference on Concurrent Engineering: Research and Applications, Toronto, ON, Canada, 26-28 August 1996; Technomic Publishing Co. Inc.: Lancaster, PA, USA, 1996; pp. 31-39.

8. Thomas, S.R.; Tucker, R.L.; Kelly, W.R. Critical communications variables. J. Constr. Eng. Manag. 1998, 124, 58-66. [CrossRef]

9. Sobotka, A.; Radziszewska-Zielina, E.; Plebankiewicz, E.; Zima, K.; Kowalik, M. Realizacja robót ziemnych w opinii wykonawców budowlanych. Prz. Nauk. Inż. Ksztatt. Śr. 2014, 63, 3-13.

10. Xie, X.; Thorpe, A.; Baldwin, A.N. A survey of communication issues in construction design. In Proceedings of the 16th Annual ARCOM Conference, Glasgow, UK, 6-8 September 2000; Akintoye, A., Ed.; Caledonian University Glasgow, Association of Researchers in Construction Management: Glasgow, UK, 2000; Volume 2, pp. 771-780. 
11. Zulch, B.G. Communication: The foundation of project management. Proc. Technol. 2014, 16, 1000-1009. [CrossRef]

12. Hoezen, M.; Reymen, I.; Dewulf, G.P.M.R. The problem of communication in construction. In Proceedings of the ADAPTABLES 2006: Proceedings of the Joint CIB, Tensinet, IASS International Conference on Adaptability in Design and Construction; Scheublin, F., Pronk, A., Prins, M., Emmitt, S., den Otter, A., Eds.; Eindhoven University of Technology: Eindhoven, The Netherlands, 3-5 July 2006; 2006; pp. 12-19.

13. Laufer, A.; Shapira, A.; Telem, D. Communicating in Dynamic Conditions: How Do On-Site Construction Project Managers Do It? J. Manag. Eng. 2008, 24, 75-86. [CrossRef]

14. Chen, Y.; Kamara, J. The Mechanisms of Information Communication on Construction Sites. Forum Ej. 2008, $8,1-32$.

15. Knotten, V.; Lædre, O.; Hansen, G. Building design management-Key success factors. Arch. Eng. Des. Manag. 2017, 13, 479-493. [CrossRef]

16. Cabała, P. Zastosowanie współczynnika konkordancji w pomiarze zgodności ocen ekspertów. Prz. Statyst. 2010, 57, 36-52.

17. Mruk, H. Komunikowanie Się W Marketing; Polskie Towarzystwo Ekonomiczne: Warszawa, Poland, 2004; ISBN 83-208-1523-1.

18. Den Otter, A.F.; Prins, M. Architectural design management within the digital design team. Eng. Const. Arch. Manag. 2002, 9, 162-173. [CrossRef]

19. Olusegun, A.E. Communications in the Building Industry of Nigeria-Implications for Clients; AIP Publishing LLC.: Melville, NY, USA, 2004; pp. 51-56.

20. Norouzia, N.; Shabakb, M.; Rashid Bin Embic, M.; Khand, T.H. The architect, the client and effective communication in architectural design practice. Proc. Soc. Behav. Sci. 2015, 172, 635-642. [CrossRef]

21. Onyegiri, I.; Nwachukwu, C. Information and communication technology in the construction industry. AJSIR 2011, 2, 461-468. [CrossRef]

22. Dainty, A.; Moore, D.; Murray, M. Communication in Construction: Theory and Practice; Taylor\&Francis: Abingdon, UK, 2006.

23. Hamilton, P.H.; Rhodes, R.G.; Wells, C.S. Communication in design. In Curriculum for Design: Preparation Material for Design Teaching; Library Edition; SEED: Loughborough, UK, 1997; pp. 1-20.

24. Higgin, G.; Jessop, N. Communication in the Building Industry: The Report of a Pilot Study; Tavistock: London, UK, 1965.

25. Wallace, W.A. The Influence of Design Team Communication Content Upon the Architectural Decision Making Process in the Pre Contract Design Stages. Ph.D. Thesis, Heriot-Watt University, Edinburgh, UK, 1987.

26. Parker, H.W. Communication: Key to productive construction. Issues Eng. 1980, 106, 173-180.

27. Gorse, C.A.; Emmitt, S.; Lowis, M. Problem solving and appropriate communication medium. In Proceedings of the 15th Annual ARCOM Conference, Liverpool John Moores University, Liverpool, UK, 15-17 September 1999; Hughes, W., Ed.; Association of Researchers in Construction Management: Glasgow, UK, 1999; Volume 2, pp. 511-518.

28. Dawood, N.; Akinsola, A.; Hobbs, B. Development of automated communication of system for managing site information using internet technology. Autom. Constr. 2002, 11, 557-572. [CrossRef]

29. Azam, M.A.M.; Ross, A.D.; Fortune, C.J.; Jaggar, D. An information strategy to support effective construction design decision making. In Proceedings of the 14th Annual ARCOM Conference, University of Reading, Reading, UK, 9-11 September 1998; Hughes, W., Ed.; Association of Researchers in Construction Management: Glasgow, UK, 1998; Volume 1, pp. 248-257.

30. Hill, C.J. Communication on construction sites. In Proceedings of the 11th Annual Conference, University of York, York, UK, 18-20 September 1995; Association of Researchers in Construction Management: Glasgow, UK, 1995; pp. 232-240.

31. Swaffield, L.M. Improving Early Cost Advice for Mechanical and Electrical Services. Ph.D. Thesis, Loughborough University of Technology, Loughborough, UK, 1998.

32. Swan, W.; Cooper, R.; McDermott, P.; Wood, G. Reviews of social network analysis for the IMI trust in construction project. In Proceedings of the 17th Annual Conference, University of Salford, Salford, UK, 5-7 September 2001; Association of Researchers in Construction Management: Glasgow, UK, 2001; pp. 59-67. 
33. Mutti, C.N.; Hughes, W. Contemporary organizational theory in the management of construction projects. In Proceedings of the 17th Annual Conference, University of Salford, Salford, UK, 5-7 September 2001; Association of Researchers in Construction Management: Glasgow, UK, 2001; pp. 455-465.

34. Cook, M.; Pasquire, C. The relationship between the management of design projects and improved performance in the building services sector of the construction industry. In Proceedings of the 17th Annual Conference, University of Salford, Salford, UK, 5-7 September 2001; Association of Researchers in Construction Management: Glasgow, UK, 2001; pp. 723-730.

35. Gushgari, S.K.; Francis, P.A.; Saklou, J.H. Skills critical to long-term profitability of engineering firms. J. Manag. Eng. 1997, 13, 46-56. [CrossRef]

36. Zakeri, M.; Olomolaiye, P.O.; Holt, G.; Harries, F.C. A survey of constraints on Iranian construction operatives' productivity. Constr. Manag. Econ. 1996, 14, 417-426. [CrossRef]

37. Betney, T. Poor communication causes defects. Constr. Manag. 1997, 3, 5.

38. Chan, A.P.C.; Chan, D.W.M.; Chiang, Y.H.; Tang, B.S.; Chan, E.H.W.; Ho, K.S.K. Exploring critical success factors for partnering in construction projects. J. Constr. Eng. Manag. 2004, 130, 188-198. [CrossRef]

39. Ng, S.T.; Rose, T.M.; Mak, M.; Chen, S.E. Problematic issues associated with project partnering: The contractor perspective. Int. J. Proj. Manag. 2002, 20, 437-449. [CrossRef]

40. Cheng, E.W.L.; Li, H.; Love, P.E.D. Establishment of critical success factors for construction partnering. J. Manag. Eng. 2000, 16, 84-92. [CrossRef]

41. Meng, X. The effect of relationship management on project performance in construction. Int. J. Proj. Manag. 2012, 30, 188-198. [CrossRef]

42. Radziszewska-Zielina, E. Assessment methods of partnering relations of Polish, Slovak and Ukrainian construction enterprises with the use of fuzzy logic. Arch. Civ. Eng. 2011, 57, 87-118. [CrossRef]

43. Radziszewska-Zielina, E.; Szewczyk, B. Controlling partnering relations in construction operations using fuzzy reasoning. Arch. Civ. Eng. 2015, 61, 89-104. [CrossRef]

44. Radziszewska-Zielina, E.; Szewczyk, B. The model of partner relationships' impact on time, cost, quality and safety in construction projects. In Proceeding of the International Scientific Conference People, Buildings and Environment 2014; 15-17 October 2014; Brno University of Technology, Faculty of Civil Engineering, Conference Proceedings: Kroměříž, Czech Republic, 2014; Volume 3, pp. 384-393.

45. Radziszewska-Zielina, E.; Szewczyk, B. Supporting partnering relation management in the implementation of construction projects using AHP and fuzzy AHP methods. Proc. Eng. 2016, 161, 1096-1100. [CrossRef]

46. Love, P.E.D.; Irani, Z.; Li, H.; Cheng, E. An empirical analysis of IT/IS evaluation in construction. J. Constr. Inf. Technol. 2001, 8, 15-27.

47. Den Otter, A.; Emmitt, S. Exploring effectiveness of team communication: Balancing synchronous and asynchronous communication in design teams. Eng. Constr. Arch. Manag. 2007, 14, 408-419. [CrossRef]

48. Jelonek, D.; Nowakowska-Grunt, J.; Ziora, L. The Assessment of Construction Project Management Maturity Level in the Silesian Region in Poland. Adv. Mater. Res. 2014, 1020, 796-802.

49. Dubas, S.; Pasławski, J. The concept of improving communication in BIM during transfer to operation phase on the Polish market. Proc. Eng. 2017, 208, 14-19. [CrossRef]

50. Radziszewska-Zielina, E.; Kania, E. Problems in Carrying Out Construction Projects in Large Urban Agglomerations on the Example of the Construction of the Axis and High5ive Office Buildings in Krakow. Matec Web Conf. 2017, 117, 00144. [CrossRef]

51. Radziszewska-Zielina, E.; Kania, E.; Śladowski, G. Problems of the Selection of Construction Technology for Structures of Urban Aglomerations. Arch. Civ. Eng. 2018, 64, 55-71. [CrossRef]

52. Śladowski, G.; Radziszewska- Zielina, E.; Kania, E. Analysis of self-organising networks of communication between the participants of a housing complex construction project. Arch. Civ. Eng. 2019, 65, 181-195. [CrossRef]

53. Radziszewska- Zielina, E.; Śladowski, G.; Kania, E.; Sroka, B.; Szewczyk, B. Managing Information Flow in Self-Organising Networks of Communication Between Construction Project Participants. Arch. Civ. Eng. 2019, 65, 133-148. [CrossRef]

54. Austin, S.; Baldwin, A.; Newton, A. Modelling design information in a design and build environment. In Proceedings of the 9th Annual Conference, Oxford University, Oxford, UK, 14-16 September 1993; Association of Researchers in Construction Management: Glasgow, UK, 1993; pp. 73-84. 
55. Yap, J.B.H.; Skitmore, M. Ameliorating time and cost control with project learning and communication management: Leveraging on reusable knowledge assets. Int. J. Manag. Proj. Bus. 2020, 13, 767-792. [CrossRef]

56. Shirazi, A.; Hampson, K. Project manager competencies in a knowledge based society. In Proceedings of the 14th Annual Conference, University of Reading, Reading, UK, 9-11 September 1998; Association of Researchers in Construction Management: Glasgow, UK; pp. 50-59.

57. Cheung, S.; Yiu, T.W.; Lam, M.C. Interweaving Trust and Communication with Project Performance. J. Constr. Eng. Manag. 2013, 139, 941-950. [CrossRef]

58. Aiyewalehinmi, E. Factor Analysis of Communication in the Construction Industry. Int. J. Eng. Sci. 2013, 2, 49-57.

59. Chiu, M.L. An organizational view of design communication in design collaboration. Des. Stud. 2002, 23, 187-210. [CrossRef]

60. Zhang, R.; Liu, A.M.M.; Chan, I.Y.S. Effects of Quality and Quantity of Information Processing on Design Coordination Performance. World J. Eng. Technol. 2018, 6, 41-49. [CrossRef]

61. Chinowsky, P.; Taylor, J.; Di Marco, M. Project Network Interdependency Alignment: New Approach to Assessing Project Effectiveness. ASCE J. Manag. Eng. 2011, 27, 170-178. [CrossRef]

62. Hossain, L. Communications and coordination in construction projects. Construct. Manag. Econ. 2009, 27, 25-39. [CrossRef]

63. Pryke, S.; Badi, S.; Almadhoob, H.; Soundararaj, B.; Addyman, S. Self-organizing networks in complex infrastructure projects. Proj. Manag. J. 2018, 49, 18-41. [CrossRef]

64. Gardounis, F.; Chong, H.; Wang, X. A conceptual framework for Social Network Analysis of Building Information Modelling in construction projects. In Proceedings of the 2017 International Conference on Research and Innovation in Information Systems (ICRIIS), Langkawi, Malaysia, 16-17 July 2017; pp. 1-6. [CrossRef]

65. Jafari, P.; Mohamed, E.; Lee, S.; Abourizk, S. Social network analysis of change management processes for communication assessment. Autom. Constr. 2020, 118, 103292. [CrossRef]

66. Thamhain, H.J.; Wilemon, D.L. Criteria for controlling projects according to plan. Proj. Manag. J. 1986, $17,75-81$.

67. Olanrewaju, A.; Tan, S.Y.; Kwan, L.F. Roles of Communication on Performance of the Construction Sector. Proc. Eng. 2017, 196, 763-770. [CrossRef]

68. Berenger, Y.R.; Justus, N.A. The Issue of Communication in the Construction Industry: A case of South Africa. In Proceedings of the Joint International Conference (JIC) on 21st Century Human Habitat: Issues, Sustainability and Development, Akure, Nigeria, 21-24 March 2016; Ebohon, O.J., Ayeni, D.A., Egbu, C.O., Omole, F.K., Eds.; South Bank University School of Architecture \& Civil Engineering: London, UK, 2016; pp. 1729-1738.

69. Bowen, P.; Edwards, P. Interpersonal communication in cost planning during the building design phase. Constr. Manag. Econ. 1996, 14, 395-404. [CrossRef]

70. Preece, C.; Stocking, S. Safety communications management in construction contracting. In Proceedings of the 15th Annual ARCOM Conference, Liverpool John Moores University, Liverpool, UK, 15-17 September 1999; Hughes, W., Ed.; Association of Researchers in Construction Management: Glasgow, UK, 1999; Volume 2, pp. 529-539.

71. Abudayyeh, O. Partnering: A team building approach to quality construction management. J. Manag. Eng. 1994, 10, 26-29. [CrossRef]

72. Harback, H.F.; Basham, D.L.; Buhts, R.E. Partnering paradigm. J. Manag. Eng. 1994, 10, 23-27. [CrossRef]

73. DeVilbiss, C.E.; Leonard, P. Partnering is the foundation of a learning organization. J. Manag. Eng. 2000, 16, 47-57. [CrossRef]

74. Black, C.; Akintoye, A.; Fitzgerald, E. An analysis of success factors and benefits of partnering in construction. Int. J. Proj. Manag. 2000, 18, 423-434. [CrossRef]

75. Gamil, Y.; Rahman, I.A. Identification of Causes and Effects of Poor Communication in Construction Industry: A Theoretical Review. Emerg. Sci. J. 2017, 1, 239-247. [CrossRef]

76. Emmitt, S.; Gorse, C. Communication in Construction Teams; Routledge: New York, NY, USA, 2007.

77. Muller, R.; Turner, J.R. The impact of principal-agent relationship and contract type on communication between project owner and manager. Int. J. Proj. Manag. 2005, 23, 398-403. [CrossRef] 
78. Malisiovas, A.; Song, X. Social Network Analysis (SNA) for Construction Projects' Team Communication Structure Optimization. Constr. Res. Congr. 2014, 2032-2042. [CrossRef]

79. Larsen, J.K.; Shen, G.Q.; Lindhard, S.M.; Brunoe, T.D. Factors affecting schedule delay, cost overrun, and quality level in public construction projects. J. Manag. Eng. 2015, 32, 04015032. [CrossRef]

80. Liu, J.; Li, B.; Lin, B.; Nguyen, V. Key issues and challenges of risk management and insurance in China's construction industry: An empirical study. Ind. Manag. Data Syst. 2007, 107, 382-396. [CrossRef]

81. Assaf, S.A.; Al-Hejji, S. Causes of delay in large construction projects. Int. J. Proj. Manag. 2006, $24,349-357$. [CrossRef]

82. Zidane, Y.; Andersen, B. The top 10 universal delay factors in construction projects. Int. J. Manag. Proj. Bus. 2018. [CrossRef]

83. Durdyev, S.; Hosseini, M. Causes of delays on construction projects: A comprehensive list. Int. J. Manag. Proj. Bus. 2019, 13, 20-46.

84. Leśniak, A.; Plebankiewicz, E. Opóźnienia w robotach budowlanych. Zeszyty Naukowe WSOWL 2010, 157, 332-339.

85. Love, P.E.D.; Li, H.; Mandal, P. Rework: A symptom of a dysfunctional supply-chain. Eur. J. Purch. Suppl. Manag. 1999, 5, 1-11. [CrossRef]

86. Love, P.E.D.; Mandal, P.; Li, H. Determining the casual structure of rework influences in construction. Constr. Manag. Econ. 1999, 17, 505-517. [CrossRef]

87. Fayek, A.R.; Dissanayake, M.; Campero, O. Measuring and Classifying Construction Field Rework: A Pilot Study; Research Rep.; Construction Owners Association of Alberta_COAA_, The University of Alberta: Edmonton, AL, Canada, 2003.

88. Hwang, B.G.; Thomas, S.R.; Haas, C.T.; Caldas, C.H. Measuring the Impact of Rework on Construction Cost Performance. J. Constr. Eng. Manag. 2009, 135, 187-198. [CrossRef]

89. Boon Hui, J.Y.; Abdul-Rahman, H.; Chen, W. Design Change Dynamics in Building Project: From Literature Review to A Conceptual Framework Formulation. J. Surv. Constr. Property 2017, 8, 13-33. [CrossRef]

90. Kamalirad, S.; Kermanshachi, S.; Shane, J.; Anderson, S. Assessment of Construction Projects' Impact on Internal Communication of Primary Stakeholders in Complex Projects. In Proceedings of the 6th CSCE International Construction Specialty Conference, Vancouver, ON, Canada, 31 May-3 June 2017.

91. Safapour, E.; Kermanshachi, S.; Taneja, P. Investigation and Analysis of the Rework Leading Indicators in Construction Projects: State-of-the-Art Review. In Proceedings of the 7th CSCE International Construction Specialty Conference, Laval, Canada, 12-15 June 2019.

92. Safapour, E.; Kermanshachi, S. Investigation and Analysis of Human, Organizational, and Project Based Rework Indicators in Construction Projects. In Proceedings of the Computing in Civil Engineering 2019: Data, Sensing, and Analytics, Atlanta, GA, USA, 13 June 2019; American Society of Civil Engineers: Reston, VA, USA, 2019.

93. Calvert, R.E.; Bailey GColes, D. Introduction to Building Management, 6th ed.Laxton's: Oxford, UK, 1995.

94. Harvey, R.C.; Ashworth, A. The Construction Industry of Great Britain, 2nd ed.; Butterworth-Heinemann: Oxford, UK, 1997.

95. Gorse, C.A. Effective Interpersonal Communication and Group Interaction During Construction Management and Design Team Meetings. Ph.D. Thesis, University of Leicester, Leicester, UK, 2002.

96. Pandit, B.; Albert, A.; Patil, Y. Developing construction hazard recognition skill: Leveraging safety climate and social network safety communication patterns. Constr. Manag. Econ. 2020. [CrossRef]

97. Albert, A.; Hallowell, M. Modeling the Role of Social Networks on Hazard Recognition and Communication. Pract. Period. Struct. Des. Constr. 2017, 22, 04017016. [CrossRef]

98. Alsamadani, R.; Hallowell, M.; Javernick-Will, A. Measuring and Modeling Safety Communication in Small Work Crews in the US using Social Network Analysis. Constr. Manag. Econ. 2013, 31, 568-579. [CrossRef]

99. Cigularov, K.; Chen, P.; Rosecranceb, J. The effects of error management climate and safety communication on safety: A multi-level study. Accid. Anal. Prev. 2010, 42, 1498-1506. [CrossRef] [PubMed]

100. Kines PAndersen, L.; Spangenberg, S.; Mikkelsen, K.; Dyreborg, J.; Zohar, D. Improving construction site safety through leader-based verbal safety communication. J. Saf. Res. 2010, 41, 399-406. [CrossRef]

101. Liao, P.; Lei, G.; Fang, D.; Liu, W. The relationship between communication and construction safety climate in China. KSCE J. Civ. Eng. 2014, 18, 887-897. [CrossRef] 
102. Kaskutas, V.; Dale, A.M.; Lipscomb, H.; Evanoff, B. Fall prevention and safety communication training for foremen: Report of a pilot project designed to improve residential construction safety. J. Saf. Res. 2013, 44, 111-118. [CrossRef]

103. Tutt, D.; Pink, S.; Dainty, A.R.; Gibb, A. In the air' and below the horizon: Migrant workers in UK construction and the practice-based nature of learning and communicating OHS. Constr. Manag. Econ. 2013, 31, 515-527. [CrossRef]

104. Hofmann, D.A.; Stetzer, A. The role of safety climate and communication in accident interpretation: Implications for learning from negative events. Acad. Manag. J. 1998, 41, 644-657.

105. Pandit, B.; Albert, A.; Patil, Y.; Al-Bayati, A.J. Fostering safety communication among construction workers: Role of safety climate and crew-level cohesion. Int. J. Environ. Res. Public Health 2019, 16, 71. [CrossRef]

106. Ghodrati, N.; Yiu, T.W.; Wilkinson, S. Unintended consequences of management strategies for improving labor productivity in construction industry. J. Saf. Res. 2018, 67, 107-116. [CrossRef]

107. Hoła, B.; Polak, A. Zarządzanie procesowe w budownictwie. Prz. Bud. 2012, 9, 55-58.

108. CII-Construction Industry Institute. Search of Partnering Excellence; Special Publication No. 17-1; Partnering Task Force of CII: Austin, TX, USA, 1991.

109. Cowan, C.; Gray, C.; Larson, E. Project partnering. Proj. Manag. J. 1992, 22, 5-12.

110. Uher, E.T. Partnering performance in Australia. J. Constr. Procur. 1999, 5, 163-176.

111. Cheng, E.; Li, H. Construction partnering process and associated critical success factors: Quantitative investigation. J. Manag. Eng. 2002, 18, 194-202. [CrossRef]

112. Xie, C.; Wu, D.; Luo, J.; Hu, X. A case study of multi-team communications in construction design under supply chain partnering. Suppl. Chain Manag. Int. J. 2010, 15, 363-370. [CrossRef]

113. Chan, A.; Chan, D.; Fan, L.; Lam, P.; Yeung, J. Partnering for construction excellence-a reality or myth? Build. Env. 2006, 41, 1924-1933. [CrossRef]

114. Szewczyk, B.; Radziszewska-Zielina, E. IT-based control and assessment of partnering relations in construction projects. Autom. Constr. 2020, 116, 103201. [CrossRef]

115. Tabish, S.; Neeraj Jha, K. Identification and evaluation of success factors for public construction projects. Constr. Manag. Econ. 2011, 29, 809-823. [CrossRef]

116. Toor, S.; Ogunlana, S. Construction professionals' perception of critical success factors for large-scale construction projects. Constr. Innov. Inf. Process. Manag. 2009, 9, 149-167. [CrossRef]

117. Shahu, R.; Pundir AKGanapathy, L. An Empirical Study on Flexibility: A Critical Success Factor of Construction Projects. Glob. J. Flex Syst. Manag. 2012, 13, 123-128. [CrossRef]

118. Chua, D.; Kog, Y.C.; Loh, P.K. Critical Success Factors for Different Project Objectives. J. Constr. Eng. Manag. 1999, 125, 142-150. [CrossRef]

119. Chan, A.; Chan, A. Key performance indicators for measuring construction success. Benchmark. Int. J. 2004, 11, 203-221. [CrossRef]

120. Chen, Y.; Zhang, Y.; Junying, L.; Peng, M. Interrelationships among Critical Success Factors of Construction Projects Based on the Structural Equation Model. J. Manag. Eng. 2012, 28, 243-251. [CrossRef]

121. Sanvido, V.; Grobler, F.; Parfitt, K.; Guvenis, M.; Coyle, M. Critical success factors for construction projects. J. Constr. Eng. Manag. 1992, 118, 94-111. [CrossRef]

122. Yang, J.; Qiping Shen, G.; Ho, M.; Drew DChan, A. Exploring critical success factors for stakeholder management in construction projects. J. Civ. Eng. Manag. 2009, 15, 337-348. [CrossRef]

123. Stabryła, A. Zarzadzanie Strategiczne w Teorii i Praktyce Firmy; Wydawnictwo Naukowe PWN: Warszawa, Poland, 2005.

124. Gorelik, A.L.; Abaev, L.C. Calculating the concordance coefficient of expert judgments in group choice and decision making. Cybern. Syst. Anal. 1990, 26, 393-399. [CrossRef]

Publisher's Note: MDPI stays neutral with regard to jurisdictional claims in published maps and institutional affiliations. 